\title{
Geographical view on energetic sources of climate northeastern Montenegro
}

\author{
Goran Rajović ${ }^{1, *}$, Jelisavka Bulatović ${ }^{2, * *}$ \\ ${ }^{1}$ Street Vojvode Stepe 252, Belgrade, Serbia \\ Phone: 0038161/19-24-850 \\ ${ }^{2}$ Department of Technology and Management, The College of Textile Design, \\ Street Starine Novaka 20, Belgrade, Serbia \\ Phone: 003861/ 3082651 \\ ${ }^{*, \star \star E-m a i l ~ a d d r e s s: ~ d k g o r a n . r a j o v i c @ g m a i l . c o m ~, ~ j e l i s a v k a . b u l a t o v i c @ g m a i l . c o m ~}$
}

\begin{abstract}
This paper analyzes energy sources climate northeastern Montenegro, in the example municipalities Berane, Andrijevica and Plav in a geographical context its exploitation and use. Analyzed GeoScape from the standpoint of utilization of wind energy lose their its attractiveness due to high altitude mountain ranges that dominate in given area, it is the windy areas, often the located on slopes of the mountains, and most of them did not connected to the existing road network and infrastructure. The use of solar thermal energy is possible only with the help of passive solar architecture and active solar architecture (solar collectors for water heating and space heating in homes and tourist facilities). Program development and use of renewable energy in Montenegro, given the Energy Law of 2010 in which Montenegro has implemented parts of EU directive 2009/28/EC on the promotion of energy from renewable sources.
\end{abstract}

Keywords: Northeastern Montenegro; climate; wind energy; solar energy

\section{INTRODUCTION}

The need to use renewable sources of energy reported the past few decades, as are disclosed alarming data on the consequences of the emission of greenhouse gases resulting from the combustion of fossil fuels. This has led to climate change in the world, which is primarily having reflected in the increase of average temperature and global warming [1-3].

Climate changes did not bypass Montenegro temperature rise since the beginning of the eighties of the last century, due to climatic disturbances can expect arid and hot summers and extreme changes in weather conditions, temperature oscillations, periods of unstable climate phenomena such as floods and town. In recent years all over the world, especially in the European Union has been a sudden increased usage of all forms of renewable energy. Today in the European Union of renewable energy, the average produces about $17 \%$ of energy. Local communities, entrepreneurs and households are investing in systems for the production of green energy, because of that they have multiple benefits. In addition to the ecological, the use renewable sources of energy has economic value may contribute to reducing the import of 
fossil fuels, the development of local industries and creating new jobs, and provide cost savings to households [4-9].

In addition to technological challenges, underdeveloped markets and lack of experience in Montenegro, greater use of renewable energy and make it difficult legal and administrative obstacles for investors. The new energy law of Montenegro adopted in 2010 should address these obstacles and improve conditions for investment. The development program and use of renewable energy is have defined as the period of 10 years in accordance with the Energy Development Strategy, based on Article 17 of the Energy Law. Therefore, program development and use of renewable energy, defines the dynamics of utilization of natural resources and the planned use of the technology needed to meet the national goal percentage share of energy from renewable sources in gross final energy consumption. The Energy Law Montenegro has implemented parts of EU directive 2009/28/EC on the promotion of energy from renewable sources in the electricity and energy for heating and / or cooling. Based on this directive defines the form of the National Action Plan for Renewable Energy Sources [10]. Since, is our object of study northeastern Montenegro, a significant prerequisite for successful use of energy resources is certainly knowledge of the available energy potential climate analyzed geographic space.

\section{RESEARCH METHODOLOGY}

This research aims to provide a review of the climate energy sources in northeastern Montenegro, in the geographical context of its exploitation and use. Objective of this study it was possible to realize the combined use of different research methods. The core methodological procedure used in this study is the geographic (spatial) method, whose scope of research has related to the municipality Berane, Andrijevica and Plav. It is in fact geographical unit which comprises $10,8 \%$ of the total area of Montenegro $\left(13.812 \mathrm{~km}^{2}\right)$, that is, living in the territory, $8,12 \%$ (54.658 population) of the population compared to the total population of Montenegro in 2003 (673.094) [11-12]. Place in the research I have found their following methods: descriptive, a causal, comparative method and theoretical analysis. Descriptive and causal methods are have been used for comparative data on the use of solar energy and wind energy. The time movement of the two meteorological elements is complementary. Usually it is most having pronounced in the annual cycle. While solar energy has a maximum in the summer of the year, wind energy is usually a maximum in winter. Methods of theoretical analysis encompassed theoretical basis of the research. The combination of these methods it is possible to validly defined achieve the research goals, which is related to the energy sources of the climate in northeastern Montenegro, for example, the municipality Berane, Andrijevica and Plav. In the scientific explanation of terms, have applied the two methods are used: the method of analysis and synthesis methods. The method of analysis we were able to deconstructed the complex notions and courts in research and bring out conclusions as to their simpler components and elements. Synthesis methods included is way of systematization of knowledge according to the laws of formal logic, a process of theoretical knowledge in the direction of special to general [13-14].

\section{ANALYSIS AND DISCUSSION}

Climate has specific energetic properties, which have used to generate electricity. Word is here about wind power and solar energy. At a time when efforts are being made for come 
up with alternative sources of energy, this energy and attention they deserve because the word of inexhaustible energy sources and energy sources such use does not cause the degradation of the other elements of the natural environment. The future development of the energy sector in Montenegro should rely on renewable energies. This position provides plenty of room for future investments in green energy. The first thorough study in this direction came in 2007 at the proposal of the Ministry of Environment and Physical Planning of Montenegro and the Montenegrin Ministry of Economy, "Assessing the potential of renewable energy sources in the Republic of Montenegro", which is done Ministry for the Environment, Land and Sea of Italy in 2007 [15].

By considering only the most suitable area for installation wind generator (with capacity factors greater than $25 \%$ ), the Ministry of Environment, Land and Sea Italy, concludes that the Republic of Montenegro disposes wind energy potential of $100 \mathrm{MW}$, counting only the most windy areas (where wind speeds above $7 \mathrm{~m} / \mathrm{s}$ ). If we take into account the areas with medium potential, this value reaches nearly $400 \mathrm{MW}$. Utilization of the aforementioned energy potential for electricity generation could provide $20-25 \%$ of annual energy consumption in Montenegro. According to the same study from [15], the most attractive locations for the exploitation of wind energy potential in Montenegro are riparian zone (the area Rumije, hinterland Petrovac, hinterland Herceg Novi, Orahovac, mountain Lovćen, hills around Nikšić). In all these areas, average wind speed exceeds $6 \mathrm{~m} / \mathrm{s}$, while the hills around Nikšić characterized by average wind speed in the range of 5.5-6.5 m/s. However, in the analysis of "Assessing the potential of renewable energy in Republic Montenegro" [15], Ministry of Environment, Land and Sea Republic of Italy, concluded that most of the areas within in interior of Montenegro, including their northeastern part, characterized by great wind speeds. However, these are areas which are mostly from the point of exploitation of wind energy are lost its attractiveness due to high altitude mountain ranges that dominate in a given area. It is the windiest areas are often located on the slopes of the mountains and most of them not connected to the existing road network and infrastructure, and in many cases was observed and a significant distance of these areas from the mains.

According Dinic [16], thresholds respectively, the possibility of using of wind energy is contained in several parameters, which can serve as a starting point for their energy evaluation. Code the wind, the basic requirement is to reaches a minimum speed of $3-4 \mathrm{~m} /$ $\mathrm{sec}$, followed, to have a certain consistency in terms of direction and frequency of occurrence. Wind rose on both stations in this part of northeastern Montenegro, show that dominant (winds from three quadrants measurement of meteorological elements performed only at meteorological stations in the Berane and Plav, that based on the data climate on meteorological station Berane judge a state of on climate territory municipal Andrijevica). At the station Berane dominant winds from the $\mathrm{S}$ and $\mathrm{N}$ quadrants, while the station Plav from the N, NE and SW quadrants. In terms of wind speed in Berane dominated by winds from the $\mathrm{S}$ quadrant and the highest average speed is 3,7 SW wind 2,7 and S winds, while the Plav has the greatest average speed SW, NW winds of 2,6. Taking in consider the study "Evaluation of the potential of renewable energy sources in the Republic of Montenegro", by the Ministry of Environment, Land and Sea Republic of Italy (2007), from the point of utilization of wind energy may be of interest to us in this part of north-eastern Montenegro, Mountain area Bjelasica. According Radičević et al [17], exactly Mountain area Bjelasica can be potentially suitable sites for construction wind generator with average annual wind speeds of $(>6 \mathrm{~m} / \mathrm{s})$, where by measuring necessary to determine suitable micro-location (at altitudes over $800 \mathrm{~m}$ ) for the construction wind generator (total capacity of $3000 \mathrm{MW}$ ). 
Solar energy represents renewable and inexhaustible energy resource in the energy sector of the country can have a significant place. In fact, solar energy is essentially represents resource that can, in certain amounts available each country without import dependence, with the importance and the fact that it is environmentally speaking, clean energy, energy technologies which do not pollute the environment in the process of converting from the original form into a form suitable for use. If every household in Montenegro according Lambić [18], had at least one unit of solar panels that would heat the domestic hot water, would save an enormous amount of conventional energy. When it comes to heating facilities, both domestic as well as commercial and other facilities, solar energy is an attractive and cost-effective to use.

According to the study "Assessing the potential of renewable energy sources in the Republic" [15], Montenegro shows great potential for the introduction of the use of solar energy, as the number of hours of sun. Are more than 2.000 hours per year for the better part of the territory of Montenegro, and more than 2.500 hours per year along seacoast? The amount of solar radiation in Montenegro, especially in the coastal and central region, is comparable to the amount of solar radiation in Greece or southern Italy. More specifically, Podgorica has a higher annual amount of solar energy $\left(1.602 \mathrm{kWh} / \mathrm{m}^{2}\right)$ compared to the other cities of South East Europe (such as Rome and Athens). In the hinterland, number of sunshine hours exceeds the value of 2.500 hours of sunshine annually, with the most intense solar radiation during the summer, late spring and early fall. A large number of sunny hours is typical and for plains. Major differences exist between the coastal areas and the central, mountainous part of Montenegro, where solar isolation may be insufficient. The abovementioned study recommends the use of solar thermal energy in Montenegro, primarily with the help passive solar architecture and active solar architecture (solar collectors for water heating and space heating in homes and tourist facilities). Data on the duration of sunshine in the northeastern Montenegro the example municipalities Berane, Andrijevica and Plav are incomplete. In fact, duration of sunshine has measured only in Berane I to since 1983. According to the Office of Hydrometeorology of Montenegro from Podgorica [19], analyzed the geographical space the located in an area 2.000 hours or yearly isolation value in hours is $1.790^{\text {th }}$.

Limit values of solar energy, according to the Dinić [16] are contained in the following parameters:

A. Over 6 hours of daily sun isolation minimum intensity of $0,6 \mathrm{cal} / \mathrm{cm}^{2} / \mathrm{min}$ the surface which is perpendicular to the direction of the sun?

B. Cloudiness is less than $60 \%$

C. Numbers of sunny are days more than half of cloudy days.

With respect to the first parameter, it appears that the greatest benefits in northeastern Montenegro, in the example municipalities Berane, Andrijevica and Plav does not provides sheltered surface south-exposed slopes with a slope of $20^{\circ}$. Over 6 hours of daily isolation in Berane have days in the period from May to September. The highest average daily isolation has days in July (8,5 h / day) and August (8,6 h / day). In are autumn month's isolation amounts in September, $6.3 \mathrm{~h} /$ day. This regularity is consistent with the annual course of cloudiness. Specifically, the ratio of the number of clear days the number of cloudy days, it appears that the number of clear days Berane 37,9 and 55,6 in the Plav. The highest average cloudiness in Berane amounts 14.5 days in December that is $13,4 \%$ of the total annual cloud cover and in Plav, in December at 13,3 days it is $13,7 \%$ of the total annual cloudiness. The greatest number of sunny days in Berane is in August to 7.2 is $19.0 \%$ and the Plav in July is 
7,3 to $13,1 \%$. In relation to the above indicated parameters, without precise sizing of solar energy, we can say that the beginning can use solar power in July, August and September, and on the south exposed slopes with a slope of $20^{\circ}$, that is, the slope is the vertical solar rays. According to the "Handbook of energy advisers' investment in the solar system would be economically viable. In fact, two-thirds of the total solar radiation occurs in the months between May and August, when solar systems meet $100 \%$ of need for hot water. In the months such as April and September results of solar collectors meet $80 \%$ of demand for domestic hot water, and months like March and October it is possible to satisfy more than 50 $\%$ of the hot water. The difference that is needed to compensate for water heating in the winter months, it can be recovered from conventional heating systems [20].

\section{CONCLUSION}

Our research record based on similar researches Tsai and Chou [21], Popović [22], Akella et al [23], Cai et al [24], pointed out is in first, several important conclusions, when are in terms of renewable energy sources:

1. Renewable sources energy plays an important role in reducing carbon dioxide $\left(\mathrm{CO}_{2}\right)$ into the atmosphere. Reducing $\mathrm{CO}_{2}$ emissions is a policy of the European Union, so it can be expected that.

2. Montenegro and accept this policy. Increasing the share of renewable energy increases the energy stability. It also helps in improving the security of power supply by reducing dependence on imported energy resources and electricity.

3. It is having expected that renewable energy sources become economically competitive with conventional energy resources.

4. Analyzed GeoScape from the standpoint of utilization of wind energy lose their its attractiveness due to high altitude mountain ranges that dominate in given area, it is the windy areas, often the located on slopes of the mountains, and most of them did not connected to the existing road network and infrastructure.

5. The use of solar thermal energy is possible only with the help of passive solar architecture and active solar architecture (solar collectors for water heating and space heating in homes and tourist facilities).

\section{References}

[1] Thornton P., Recalibrating food production in the developing world: Global warming will change more than just the climate, CGIAR Research Program on Climate Change, Agriculture and Food Security, 2012.

[2] Vermeulen S. J., Campbell B. M., Ingram J. S., Annual Review of Environment and Resources 37(1) (2012) 195.

[3] Jotzo F., Burke P. J., Wood P. J., Macintosh A., Stern D. I., Nature Climate Change 2(4) (2012) 213-214.

[4] Karki R., Billinton R., Energy Conversion, IEEE Transactions on 16(4) (2001) 368-373.

[5] Bolonkin A., Utilization of wind energy at high altitude, AIAA Paper, 5705, 2004.

[6] Marchenko O. V., Solomin S. V., Renewable energy 29(11) (2004) 1793-1809. 
[7] Chwieduk D., Opto-electronics Review 12(1) (2004) 13-20.

[8] Lewis N. S.,Crabtree G., Basic research needs for solar energy utilization: Report of the basic energy sciences workshop on solar energy utilization, April 18-21, 2005.

[9] Lewis N. S., Nocera D. G., Proceedings of the National Academy of Sciences 103 (43) (2006) 15729-15735.

[10] Renewable energy-Montenegro, Available from: http://www.oie-res.me (04.10 2013)

[11] Rajović G., Bulatović J., International Letters of Social and Humanistic Sciences 6 (2013) 24-35.

[12] Rajović G., Bulatović J., International Letters of Social and Humanistic Sciences 6 (2013) 49-61.

[13] Rajović G., International Letters of Social and Humanistic Sciences 11 (2013) 35-46.

[14] Rajović G., Bulatović J., International Letters of Social and Humanistic Sciences 1 (2014) 51-62.

[15] Ministry for the Environment, Land and Sea Republic of Italy, Evaluation of the potential of renewable energy sources in the Republic of Montenegro,CETMA, 2007.

[16] Dinić J., Economic geography, principles and methods of spatial structure, Faculty of Economics, Belgrade, 1981.

[17] Radičević M. B., Mikičić J. D., Vukić R. Đ., Journal Agricultural Engineering 30(3) (2005) 81-89.

[18] Lambić M., Solar Energy, Available from: http://www.microma.co.rs (05.10 2013).

[19] Hydro meteorological Bureau of Montenegro, Meteorological yearbooks, Podgorica, 1993.

[20] Solar Energy, Available from: http://www.elsol.rs(06.10 2013).

[21] Tsai W. T., Chou Y. H., Renewable and Sustainable Energy Reviews 10(5) (2006) 491-502.

[22] Popović M., Wind energy, Magazine Planet, 22, Available from: http://www.oie-res.me (07.10 2013), 2007.

[23] Akella A. K., Sharma M. P., Saini R. P., Renewable and Sustainable Energy Reviews 11(5) (2007) 894-908.

[24] Cai Y. P., Huang G. H., Yang Z. F., Lin Q. G., Tan Q., Renewable and Sustainable Energy Reviews 13(4) (2009) 721-735. 